\title{
Characterization of Ladle Furnace Slag from Carbon Steel Production as a Potential Adsorbent
}

\author{
Ankica Rađenović, Jadranka Malina, and Tahir Sofilić \\ Faculty of Metallurgy, University of Zagreb, Aleja Narodnih Heroja 3, 44000 Sisak, Croatia \\ Correspondence should be addressed to Ankica Rađenović; radenova@simet.hr
}

Received 24 May 2013; Revised 5 July 2013; Accepted 1 August 2013

Academic Editor: Charles Sorrell

Copyright (C) 2013 Ankica Rađenović et al. This is an open access article distributed under the Creative Commons Attribution License, which permits unrestricted use, distribution, and reproduction in any medium, provided the original work is properly cited.

\begin{abstract}
A promising type of steel slag for applications is the ladle furnace (LF) slag, which is also known as the basic slag, the reducing slag, the white slag, and the secondary refining slag. The LF slag is a byproduct from further refining molten steel after coming out of a basic oxygen furnace (BOF) or an electric arc furnace (EAF). The use of the LF slag in further applications requires knowledge of its characteristics. The LF slag characterization in this paper has been performed using the following analytical methods: chemical analysis by energy dispersive spectrometry (EDS), mineralogical composition by X-ray diffraction (XRD), surface area properties by the Brunauer-Emmett-Teller (BET) and the Barrett-Joyner-Halenda (BJH) methods, surface chemistry by infrared absorption (FTIR) spectroscopy, and morphological analysis by scanning electron microscopy (SEM). The results showed that the main compounds are calcium, silicon, magnesium, and aluminium oxides, and calcium silicates under their various allotropic forms are the major compounds in the LF slag. Surface area properties have shown that the LF slag is a mesoporous material with relatively great BET surface area. The ladle furnace slag is a nonhazardous industrial waste because the ecotoxicity evaluation by its eluate has shown that the LF slag does not contain constituents which might in any way affect the environment harmfully.
\end{abstract}

\section{Introduction}

Many million tons of slag are generated as it is a byproduct of iron- and steelmaking industry during the separation of the molten iron and steel from impurities. There are four types of iron and steel industry slags, namely, the blast furnace $(\mathrm{BF})$ iron slag, the basic oxygen furnace (BOF) the steel slag, the electric arc furnace (EAF) steel slag, and the ladle furnace (LF) basic slag, also called the secondary refining slag or the white slag. The ladle furnace basic slag is produced in the final stages of steelmaking, when the steel is desulfurized in the transport ladle, during what is generally known as the secondary metallurgy process $[1,2]$. The most important functions of the secondary refining processes are the final desulfurization, the degassing of oxygen, nitrogen, and hydrogen, the removal of impurities, and the final decarburization (done for ultralow carbon steels) [3].

The increase in steel consumption is thus the cause of the generation of slag, and, consequently, the growth in slag volume had impact on developing various methods of slag utilization. Relevant data published during the past two decades have demonstrated the suitability of some of these materials, from both a technical and an economic perspective $[4,5]$. Slags from iron and steel production have long been regarded as useful materials in building and civil works. Steel slag can be utilized in many different areas such as soil conditioners, fertilizers, sinter material, production of cement and concrete, and so forth [6]. Each type of slag has its own characteristics such as the use of ground granulated BF iron slag, as an addition to the Portland cement. Furthermore, BOF slag and EAF slag are used in asphaltic mixes and road-base layers. The practical application of the LF slag differs from the latter due to its specific characteristics. Good examples are found in agriculture for the correction of soil acidity and in cement industry as raw material for the Portland clinker fabrication [7].

With the rapid development of industries such as metal plating facilities, mining operations, fertilizer industries, tanneries, batteries, paper industries, pesticides, and so forth, heavy metals wastewaters are directly or indirectly discharged 
into the environment increasingly, especially in the developing countries. Unlike organic contaminants, heavy metals are not biodegradable and tend to accumulate in living organisms, and many heavy metal ions are known to be toxic or carcinogenic. Hence, heavy metals are the environmental priority pollutants and are becoming one of the most serious environmental problems. Many methods that are being used to remove heavy metal ions include chemical precipitation, ion-exchange, adsorption, membrane filtration, electrochemical treatment technologies, and so forth [8].

Adsorption is the equilibrium separation process, and it is an effective method for water decontamination applications. The primary requirement for an economic adsorption process is an adsorbent with selectivity, high adsorption capacity, and low cost. Adsorption by low-cost adsorbents is recognized as an effective and economic method for heavy metal wastewater treatment as an alternative to expensive activated carbon. However, the adsorption efficiency depends on the type of adsorbents. The industrial byproducts could be assumed to be the low-cost adsorbents due to their abundance in nature and less processing requirements.

The slag as an alternative adsorbent has been used to remove heavy metals in the environmental field due to its unique properties $[9,10]$. The major heavy metal removal mechanisms are precipitation and adsorption on the surface of an adsorbent.

This paper describes the characterization of the ladle furnace slag. The investigated chemical and mineralogical properties and then the surface area data and surface morphology could predict the possible use of the LF slag as a potential adsorbent for uptaking the harmful substances from solutions.

\section{Materials and Methods}

In order to investigate the chemical and phase composition of the LF slag, the monthly samples taken at the outlet of the LF slag system were analyzed during 2011. The liquid LF slag was, after being poured out of the ladle furnace cooled in the air, subjected to the following procedures: crushing and magnetic separation in order to remove the leftover particles of the cooled steel melt and milling. The five kilos of each monthly sample were homogenized and reducing to $1000 \mathrm{~g}$ of sample The samples were transferred to glass bottles with ground cap and marked. In this way, average monthly specimens of the ladle furnace slag were created, and they were marked with numbers 1-12. One of these, as the representative sample sieved to particle size $0.125-0.063 \mathrm{~mm}$, is used for further testing.

Chemical composition of the ladle furnace slag has been determined using energy dispersive spectrometry (EDS). The ladle furnace slag samples were prepared for EDS analysis as follows: 4 grams of each powdered sample (particle size less than $0.071 \mathrm{~mm}$ in diameter) was pressed into pellets of $20 \mathrm{~mm}$ in diameter (15 tons pressure; $30 \mathrm{~s}$ dwelling time). No binder material was applied. The samples were placed in standard sample holders and loaded into the spectrometer.

Samples were irradiated by X-rays generated from a Mo tube (maximum high voltage: $40 \mathrm{kV}$; maximum current:
$900 \mu \mathrm{A})$. In order to reduce the background, filters were used between the source and the sample. Detection of characteristic X-ray radiation from the sample was conducted with a Si drift detector model SXD15C-150-500 (Canberra, Meriden, IL, USA). Active surface was $15 \mathrm{~mm}^{2}$; FWHM for $5.9 \mathrm{keV} 55 \mathrm{Fe}$ was $145 \mathrm{eV}$; window was $13 \mu \mathrm{m} \mathrm{Be}$; cooling was thermo-electrical (peltier). The incident and emerging angles were $45^{\circ}$. Spectral data were analyzed by WinAxil software (Canberra, Meriden, IL, USA). Calibration model for quantitative analyses of the LF slag was created on the basis of measurements of the following standard reference materials: BCS 174/2 basic slag i BCS 382; basic slag.

The mineralogical composition of the LF slag sample was determined by the X-ray diffraction method (XRD method) using a Philips PW3710 X-ray diffractometer (The Netherlands) equipped with a $\mathrm{CuK} \alpha$ radiation and a graphite monochromator.

The Fourier transform infrared spectroscopy (FTIR) analysis was used to identify the changes in the sample in the range from 4000 to $650 \mathrm{~cm}^{-1}$ by the Spectrum One FTIR Spectrometer, Perkin Elmer (G. Britain). Samples were characterized in their basic form without any preparation using attenuated total reflectance (ATR) chamber.

Surface area properties are determined by the BrunauerEmmett-Teller (BET) and the Barrett-Joyner-Halenda (BJH) methods using a Micromeritics ASAP 2000 (USA) adsorption instrument. The average pore diameter is calculated using the following equation: $d=4 \cdot V_{p} / S_{p}$, where $V_{p}$ is the specific volume and $S_{p}$ is the specific surface area. The pore-size distribution of the LF slag is calculated by the Barrett-Joyner-Halenda (BJH) method. Before analysis, the LF slag samples were heated at a temperature of $50^{\circ} \mathrm{C}$ and evacuated under the $666.5 \cdot 10^{-3}$ Pa pressure in order to remove any contaminants as well as moisture that might be present on the surface.

The surface morphology of the LF slag sample was examined by the method of qualitative scanning electron microscopy (SEM) using Tescan Vega TS 5136 MM microscope (Czech Republic).

The DIN38414-S4 leachate was prepared by mixing the samples with deionized distilled water for $24 \mathrm{~h}$ on a rotary shaker $(3 \mathrm{rpm})$. Solid-liquid ratio was $1 / 10$. The test was carried out at room temperature. The suspended solid matter was removed from the liquid phase by filtration through a glass fiber filter.

\section{Results and Discussion}

The collected samples of the LF slag formed within the stated time frame had the following chemical composition range: $\mathrm{CaO} 19.02 \%-51.34 \%$, mean value 35.54\%; $\mathrm{SiO}_{2} 11.30 \%-$ $30.10 \%$, mean value $22.16 \% ; \mathrm{Al}_{2} \mathrm{O}_{3} 8.54 \%-15.18 \%$, mean value $11.65 \%$; MgO 7.66\%-18.84\%, mean value $13.83 \%$; FeO 1.17\%$7.45 \%$, mean value $2.53 \%$; $\mathrm{MnO} 0.22 \%-1.34 \%$, mean value $0.48 \% ; \mathrm{Cr}_{2} \mathrm{O}_{3} 0.04 \%-0.92 \%$, mean value $0.15 \% ; \mathrm{P}_{2} \mathrm{O}_{5} 1.52 \%-$ $3.00 \%$, mean value $2.35 \% ; \mathrm{TiO}_{2} 0.08 \%-0.22 \%$, mean value $0.15 \% ; \mathrm{K}_{2} \mathrm{O} 0.19 \%-0.42 \%$, mean value $0.57 \%$; and $\mathrm{Na}_{2} \mathrm{O}$ $0.38 \%-0.56 \%$, mean value $0.46 \%$. In this work, the testing has been conducted on one of the LF slag samples whose chemical composition is shown in Table 1. 
TABLE 1: Chemical composition of the LF slag.

\begin{tabular}{lc}
\hline & Slag component (wt $\%)$ \\
\hline $\mathrm{CaO}$ & 48.37 \\
$\mathrm{SiO}_{2}$ & 15.00 \\
$\mathrm{FeO}$ & 1.54 \\
$\mathrm{Al}_{2} \mathrm{O}_{3}$ & 14.30 \\
$\mathrm{MgO}$ & 15.25 \\
$\mathrm{Na}_{2} \mathrm{O}$ & 0.43 \\
$\mathrm{~K}_{2} \mathrm{O}$ & 0.36 \\
$\mathrm{TiO}_{2}$ & 0.20 \\
$\mathrm{P}_{2} \mathrm{O}_{5}$ & 2.73 \\
$\mathrm{Cr}_{2} \mathrm{O}_{3}$ & 0.92 \\
\hline
\end{tabular}

On the basis of data on the chemical composition of steel slag, it can be concluded that their quality and composition depend on the steel scrap used as raw material, type and share in the heat of specific nonmetallic supplements, type and amount of ferroalloys, and other technological parameters. Two types of steel slags are produced in electric furnaces: the so-called black steel slag when remelting unalloyed steel waste and the white steel slag which is created during the remelting of alloyed steel waste. These two types of steel slags differ from other each by their chemical and consequentially mineral composition. The black steel slag, represents a mixture of oxides of a relatively complex chemical composition. They mostly contain calcium and iron oxides, followed by (according to representation) magnesium, silica, and aluminium oxides [11].

The results of the chemical analysis performed on the investigated LF slag are shown in Table 1. The main compounds are calcium, silicon, magnesium, and aluminium oxides representing more than $92 \%$ of the total mass. The available literature data $[3,12-14]$ show typical chemical composition of the ladle slag: $\mathrm{CaO}$ ranges from $30 \%$ to $60 \%, \mathrm{SiO}_{2}$ ranges from $2 \%$ to $35 \%, \mathrm{Al}_{2} \mathrm{O}_{3}$ ranges from $4.1 \%$ to $35.76 \%$, $\mathrm{MgO}$ ranges from $1 \%$ to $12.6 \%, \mathrm{FeO}$ ranges from $0 \%$ to $15 \%, \mathrm{MnO}$ ranges from $0 \%$ to $5 \%, \mathrm{Cr}_{2} \mathrm{O}_{3}$ ranges from $0.03 \%$ to $0.37 \%, \mathrm{P}_{2} \mathrm{O}_{5}$ ranges from $0 \%$ to $0.4 \%, \mathrm{TiO}_{2}$ ranges from $0.2 \%$ to $0.9 \%, \mathrm{~K}_{2} \mathrm{O}$ ranges from $0.01 \%$ to $0.02 \%$, and $\mathrm{Na}_{2} \mathrm{O}$ ranges from $0.06 \%$ to $0.07 \%$. Thus, the obtained results are consistent with these data. These oxides are unavoidable constituents of silicates and aluminates of the calcium and magnesium presented in the LF slags $[2,3]$. The LF slag with such composition could be considered as an effective adsorbent like other slags of the ironmaking industry. This can be related to its high oxides mass fraction $\left(\mathrm{CaO}, \mathrm{MgO}\right.$, and $\mathrm{SiO}_{2}$, Table 1$)$ as they contain oxygenated surface functional groups $[9,15,16]$.

Furthermore, as shown in Figure 1, the mineralogical compounds detected in the $\mathrm{LF}$ slag could be attributed to mayenite $\left(12 \mathrm{CaO} \cdot 7 \mathrm{Al}_{2} \mathrm{O}_{3}, \mathrm{Ca}_{12} \mathrm{Al}_{14} \mathrm{O}_{33}\right.$, and $\left.\mathrm{C}_{12} \mathrm{~A}_{7}\right)$, periclase $(\mathrm{MgO})$, gehlenite $\left(2 \mathrm{CaO} \cdot \mathrm{Al}_{2} \mathrm{O}_{3} \cdot \mathrm{SiO}_{2}, \mathrm{Ca}_{2} \mathrm{Al}_{2} \mathrm{SiO}_{7}\right)$, larnite $\quad\left(\beta-2 \mathrm{CaO} \cdot \mathrm{SiO}_{2}, \quad \beta-\mathrm{Ca}_{2} \mathrm{SiO}_{4}\right), \quad$ shannonite $(\gamma$ $\left.2 \mathrm{CaO} \cdot \mathrm{SiO}_{2}, \quad \gamma-\mathrm{Ca}_{2} \mathrm{SiO}_{4}\right), \quad$ and tricalcium aluminate $\left(3 \mathrm{CaO} \cdot \mathrm{Al}_{2} \mathrm{O}_{3}, \mathrm{Ca}_{3} \mathrm{Al}_{2} \mathrm{O}_{6}\right.$, and $\left.\mathrm{C}_{3} \mathrm{~A}\right)$. The $\mathrm{XRD}$ analysis

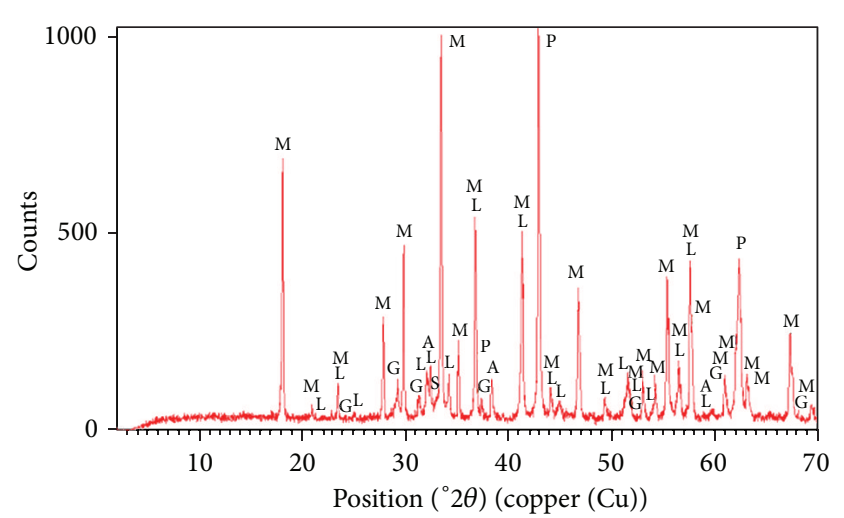
(M) Mayenite
(L) Larnite
(P) Periclase
(G) Gehlenite
(A) $\mathrm{C}_{3} \mathrm{~A}$
(S) Shannonite

FIgURE 1: The XRD pattern of the LF slag.

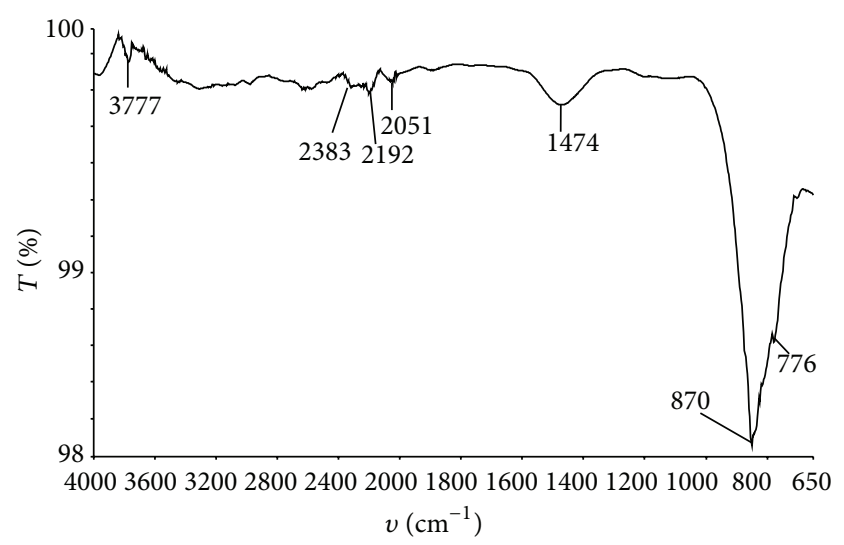

FIGURE 2: The FTIR spectrum of the LF slag.

confirmed that the slag mainly consisted of metal oxide in various oxides, silicate and aluminate forms.

The results of the XRD analysis in the investigated LF slag are comparable with the results published before $[2,3,12,14]$. Calcium silicates under their various allotropic forms are the major compounds in the LF slag.

On the contrary, steel slag from the process of production of unalloyed steel is otherwise known as black steel slag and represents a mixture of oxides of a relatively complex chemical composition. For example, dicalcium and tricalcium silicates $\left(2 \mathrm{CaO} \cdot \mathrm{SiO}_{2}, \mathrm{C}_{2} \mathrm{~S}\right.$ and $\left.3 \mathrm{CaO} \cdot \mathrm{SiO}_{2}\right)$, brownmillerite $\left(\mathrm{Ca}_{2}(\mathrm{Al}, \mathrm{Fe})_{2} \mathrm{O}_{5}\right)$, wustite $(\mathrm{FeO})$, and mayenite $\left(12 \mathrm{CaO} \cdot 7 \mathrm{Al}_{2} \mathrm{O}_{3}\right)$ are the most highly represented mineral phases detected in the earlier published work [11].

The IR spectra of the LF slag sample are presented in Figure 2. Absorptions correspond to the dominant phases: periclase and mayenite at 1474 and $870 \mathrm{~cm}^{-1}$, respectively. The peaks of 2051, 2192, 3777, and $2383 \mathrm{~cm}^{-1}$ (although weak) corresponded to periclase, $\mathrm{MgO}$.

Adsorption is a surface phenomenon, in which molecules of the adsorbate are attracted and held to the surface of 


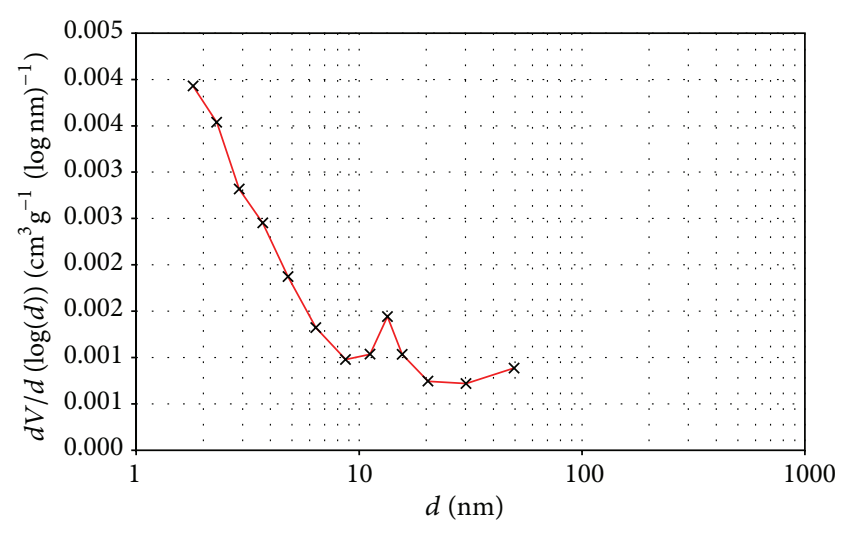

FIgURE 3: The pore-size distribution of the LF slag.

an adsorbent until an equllibrium is reached between the adsorbed molecules and those still freely distributed in the carrying gas or liquid. The adsorption depends on the interaction between the surface of the adsorbent and the adsorbed species. Hence, the area is a fundamentally important feature of the adsorbents, particularly in understanding the mechanism of adsorption. There are different mechanisms by which metallic ions (or other ions) are removed from an aqueous solution. The first states that the process is based on electrostatic adsorbate-adsorbent interactions being totally dependent on the existence of surfaces functionality, especially oxygen surfaces complexes (ion-exchange process). The second one suggests that the enhanced adsorption potentials, as occurs in the narrowest microporosity, may be strong enough to adsorb and retain ions [9]. It is obvious that most important characteristics of an adsorbent are its specific surface area, its total pore volume, and its pore-size distribution.

The LF slag has a relatively great BET surface area, $S_{\mathrm{BET}}=$ $3.04 \mathrm{~m}^{2} \mathrm{~g}^{-1}$ (according to the other iron and steel slags), which means that it might have available adsorption sites. The obtained results were similar to the results of BET surface area in the slags of steel- and ironmaking industry used as adsorbents for $\mathrm{Cu}, \mathrm{Cd}, \mathrm{Zn}, \mathrm{Ni}$, and $\mathrm{Pb}$ from aqueous solutions [1720]. The average pore diameter of the investigated LF sample is $d=3.21 \mathrm{~nm}$, and the total pore volume $(1.7-300 \mathrm{~nm})$ is $V_{p}=2.6 \cdot 10^{-3} \mathrm{~cm}^{3} \mathrm{~g}^{-1}$. The pore-size distribution of the LF slag is shown in Figure 3. The fraction of small pores $(<10 \mathrm{~nm})$ is present in the greatest proportion.

According to the IUPAC, the pores of porous material are classified into three groups: micropores (width $d<$ $2 \mathrm{~nm}$ ), mesopores ( $2 \mathrm{~nm}<d<50 \mathrm{~nm}$ ), and macropores $(d>50 \mathrm{~nm})$. Above $50 \mathrm{~nm}$ pore radius, the pore surfaces are difficult to be distinguished in properties from the external surface. On the basis of the obtained results, the LF slag may be considered a mesoporous material [21].

Besides their significant contribution to adsorption, mesopores also serve as the main transport channels for the adsorbate molecules or ions. Micropores have significant effects in the adsorption of small solute molecules. Larger molecules are excluded from micropores, but they may be

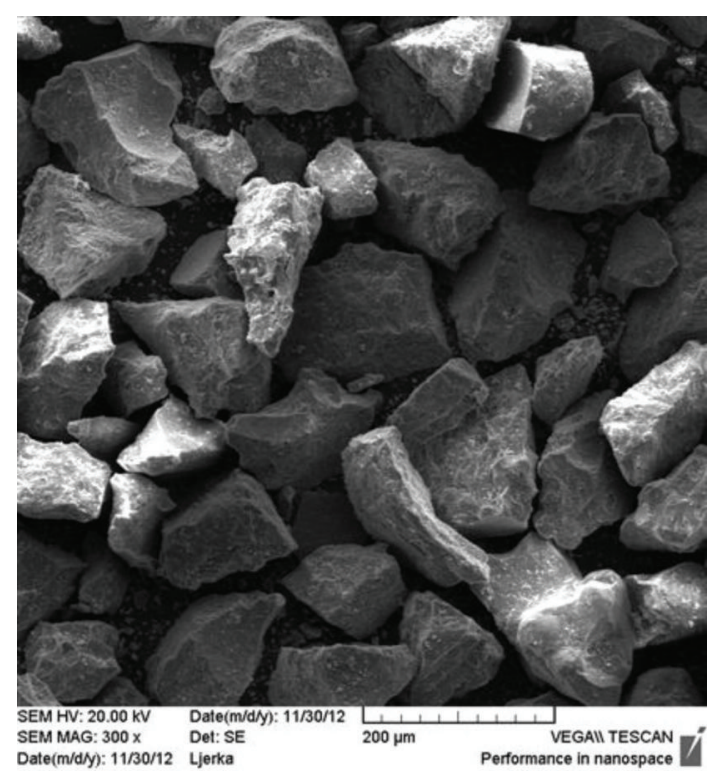

FIGURE 4: The SEM morphology of the LF slag particles.

adsorbed into some or all of the mesopores and all the macropores [22]. The mesopores have their most influence in the adsorption of organic solutes, since they are of the size which enables their surfaces to be accessible to solute molecules of this type and dimension. The surface properties of adsorbents are influenced to an extent by the foreign elements fixed on the surface, in particular by oxygen, through functional groups responsible for the reactivity of the surface [23].

The LF slag is an inhomogeneous material usually presented in a whitish dusty form. The surface morphology of LF slag particles is shown in Figure 4. The grains are sharp edged, partly dense, and partly porous. The porosity is of two types: on one hand, there are isolated round-shaped pores, whereas on the other hand, there is a system of capillary porosity and cracks. The cracks occur mainly on the periphery of the grains and are parallel with the edges of the grains.

It is of vital importance to be familiar not only with the technical significance of the secondary application of waste and/or by-product materials, but also with their possible environmental effects because some waste materials might contain increased concentrations of substances harmful to human health or the environment, especially to the water [24-26]. The environmental conformity of the LF slag has been investigated for years, which is normally judged by the leachability of the slag. Due to the very low solubility of the most mineral phases of the LF slag in water, the LF slag does not affect the environment.

All of the methods, procedures, determination tests, and ecotoxicity reviews used nowadays have been developed from the earliest method of eluating by distilled water according to the norm DIN 38414-S4 (German standard methods for the estimation of water, wastewater and sludges, soils, and sediments: Group S, 1984), where the solid-liquid ratio is $1 / 10$ and the period of mixing is 24 hours. 
TABLE 2: Results of measuring parameter values of the LF eluate.

\begin{tabular}{|c|c|c|c|}
\hline \multirow[b]{2}{*}{ Parameters } & \multirow[b]{2}{*}{ Method } & \multicolumn{2}{|c|}{$\mathrm{mg} / \mathrm{kg}$ of dry substance } \\
\hline & & $\begin{array}{l}\text { Limiting value of eluate } \\
\text { parameter }{ }^{*} \mathrm{~L} / \mathrm{S}=10 \mathrm{~L} / \mathrm{kg}\end{array}$ & $\begin{array}{c}\text { Measured value of eluate } \\
\text { parameter }\end{array}$ \\
\hline Arsenic (As) & HRN EN ISO 11969:1996 & 2 & $<0.001$ \\
\hline Barium (Ba) & DIN 38406-28 & 100 & 5.92 \\
\hline Cadmium (Cd) & DIN ISO 8288:1998 & 1 & 0.002 \\
\hline Total chromium (Cr) & HRN EN 1233:1998 & 10 & 0.15 \\
\hline Copper $(\mathrm{Cu})$ & HRN ISO 8288:1998 & 50 & 0.07 \\
\hline Mercury (Hg) & HRN EN 1483:1997 & 0.2 & $<0.001$ \\
\hline Molybdenum (Mo) & $\begin{array}{l}\text { US Standard Methods } \\
\text { 3111D }\end{array}$ & 10 & $<0.01$ \\
\hline Nickel (Ni) & HRN ISO 8288:1998 & 10 & 0.04 \\
\hline Lead $(\mathrm{Pb})$ & HRN ISO 8288:1998 & 10 & $<0.01$ \\
\hline Antimony (Sb) & DIN 38405-32-2 & 0.7 & $<0.01$ \\
\hline Selenium (Se) & HRN ISO 9965:2001 & 0.5 & $<0.01$ \\
\hline Zink (Zn) & HRN ISO 8288:1998 & 50 & 0.03 \\
\hline Chlorides $\left(\mathrm{Cl}^{-}\right)$ & HRN ISO 9297:1998 & 15000 & 63 \\
\hline Fluoride $\left(\mathrm{F}^{-}\right)$ & $\begin{array}{l}\text { HRN ISO } \\
\text { 10359:1998 }\end{array}$ & 150 & $<1$ \\
\hline Sulfates $\left(\mathrm{SO}_{4}{ }^{2-}\right)$ & HRN EN ISO 10304-1:1998 & 20000 & 10 \\
\hline Dissolved organic carbon, DOC (C) & HRN EN 1484:2002 & 800 & 36 \\
\hline Total dissolved substances & HRN EN 15216:2008 & 60000 & 9800 \\
\hline
\end{tabular}

${ }^{*} \mathrm{~L} / \mathrm{S}$ : liquid/solid.

The LF slag specimen was tested in an authorized laboratory and with the purpose of determining physical and chemical characteristics of slag waste for permanent disposal, according to the valid Croatian regulations [27]. As for the final results, Table 2 showed that the ladle furnace slag does not contain any constituent which might in any way affect the environment harmfully; thus, it can be disposed of at nonhazardous or "green" waste disposal site.

\section{Conclusions}

The characterization of the LF slag was conducted in order to obtain information relevant for its possible use as a lowcost adsorbent. Chemical analysis showed that the main compounds are calcium, silicon, magnesium, and aluminium oxides representing more than $92 \%$ of the total mass. The results of the $\mathrm{X}$-ray diffraction phase analysis confirm the earlier conclusions based on the elementary and quantitative chemical analyses. Calcium silicates under their various allotropic forms are the major compounds in the LF slags. The LF slag with such composition could be considered as an effective adsorbent like other slags of the ironmaking industry. This can be related to its high oxides mass fraction $(\mathrm{CaO}$, $\mathrm{MgO}$, and $\mathrm{SiO}_{2}$,) and aluminium silicates that contain surface functional groups important for the LF slag adsorption ability. Determination of waste ecotoxicity has been conducted by examining the composition of its eluate, and the final results showed that the ladle furnace slag does not contain any constituent which might in any way affect the environment harmfully. Microscopic observation showed that the LF slag is an inhomogeneous material with sharp-edged grains. On the basis of the surface area properties, the LF slag is a mesoporous material with a relatively great BET surface area compared with those of the other iron and steel slags.

The LF slag could be considered as a potential adsorbent due to its unique characteristics. But, the final assessment of the applicability of the LF slag as an adsorbent will give its real application in each case of the removal of substances from the aqueous solution.

\section{Conflict of Interests}

The authors confirm that there is no conflict of interests regarding the "WinAxil software" in this paper. Accordingly, the coauthors state that they do not have a direct financial relation with the trademarks mentioned in this paper.

\section{Acknowledgment}

This work was supported by the Ministry of Science, Education, and Sports of the Republic of Croatia, under Project no. 124-124 1565-1524.

\section{References}

[1] G. Stolte, Secondary Metallurgy, Stahleisen GmbH, Düsseldorf, Germany, 2002.

[2] J. Setién, D. Hernández, and J. J. González, "Characterization of ladle furnace basic slag for use as a construction material," 
Construction and Building Materials, vol. 23, no. 5, pp. 17881794, 2009.

[3] I. Z. Yildirim and M. Prezzi, "Chemical, mineralogical, and morphological properties of steel slag," Advances in Civil Engineering, vol. 2011, Article ID 463638, 13 pages, 2011.

[4] J. Geiseler, "Use of steelworks slag in Europe," Waste Management, vol. 16, no. 1-3, pp. 59-63, 1996.

[5] P. J. Koros, "Dusts, scale, slags, sludges. . .not wastes, but sources of profits," Metallurgical and Materials Transactions B, vol. 34, no. 6, pp. 769-779, 2003.

[6] H. Yi, G. Xu, H. Cheng, J. Wang, Y. Wan, and H. Chen, "An overview of utilization of steel slag," Procedia Environmental Sciences, vol. 16, pp. 791-801, 2012.

[7] R. Dippenaar, "Industrial uses of slag (the use and re-use of iron and steelmaking slags)," Ironmaking and Steelmaking, vol. 32, no. 1, pp. 35-46, 2005.

[8] F. Fu and Q. Wang, "Removal of heavy metal ions from wastewaters: a review," Journal of Environmental Management, vol. 92, no. 3, pp. 407-418, 2011.

[9] J. M. Dias, M. C. M. Alvim-Ferraz, M. F. Almeida, J. RiveraUtrilla, and M. Sánchez-Polo, "Waste materials for activated carbon preparation and its use in aqueous-phase treatment: a review," Journal of Environmental Management, vol. 85, no. 4, pp. 833-846, 2007.

[10] M. A. Barakat, "New trends in removing heavy metals from industrial wastewater," Arabian Journal of Chemistry, vol. 4, no. 4, pp. 361-377, 2011.

[11] T. Sofilić, A. Mladenoviè, and U. Sofilić, "Defining of EAF steel slag application possibilities in asphalt mixture production," Journal of Environmental Engineering and Landscape Management, vol. 19, no. 2, pp. 148-157, 2011.

[12] T. Sofilić, A. Mladenović, V. Oreščanin, and D. Barišić, "Characterization of ladle furnace slag from the carbon steel production," in Proceedings Book of the 13th International Foundrymen Conference-Innovative Foundry Processes and Materials, Opatija, Z. Glavaš, Z. Brodarac, and N. Dolić, Eds., pp. 354-369, Faculty of Metallurgy, Sisak, Croatia, 2013.

[13] C. Shi, "Steel slag-its production, processing, characteristics, and cementitious properties," Journal of Materials in Civil Engineering, vol. 16, no. 3, pp. 230-236, 2004.

[14] V. A. Rovnushkin, E. A. Visloguzova, S. A. Spirin, E. V. Shekhovtsov, V. V. Kromm, and A. A. Metelkin, "Composition of ladle slag and refractory materials and its effect on the wear resistance of the lining of an $\mathrm{RH}$ vacuum degasser," Refractories and Industrial Ceramics, vol. 46, no. 3, pp. 193-196, 2005.

[15] B. Kostura, H. Kulveitová, and J. Leško, "Blast furnace slags as sorbents of phosphate from water solutions," Water Research, vol. 39, no. 9, pp. 1795-1802, 2005.

[16] S. K. Parida, S. Dash, S. Patel, and B. K. Mishra, "Adsorption of organic molecules on silica surface," Advances in Colloid and Interface Science, vol. 121, no. 1-3, pp. 77-110, 2006.

[17] D. Kim, M. Shin, H. Choi, C. Seo, and K. Baek, "Removal mechanisms of copper using steel-making slag: adsorption and precipitation," Desalination, vol. 223, no. 1-3, pp. 283-289, 2008.

[18] X. Chen, W. H. Hou, G. L. Song, and Q. H. Wang, "Adsorption of $\mathrm{Cu}, \mathrm{Cd}, \mathrm{Zn}$ and $\mathrm{Pb}$ ions from aqueous solutions by electric arc furnace slag and the effects of $\mathrm{pH}$ and grain size," Chemical and Biochemical Engineering Quarterly, vol. 25, no. 1, pp. 105114, 2011.

[19] S. V. Dimitrova, "Use of granular slag columns for lead removal," Water Research, vol. 36, no. 16, pp. 4001-4008, 2002.
[20] N. Ortiz, M. A. F. Pires, and J. C. Bressiani, "Use of steel converter slag as nickel adsorber to wastewater treatment," Waste Management, vol. 21, no. 7, pp. 631-635, 2001.

[21] R. C. Bansal, J. B. Donnet, and F. Stoeckli, Active Carbon, Marcel Dekker, New York, NY, USA, 1988.

[22] A. P. D'Silva, "Adsorption of antioxidants by carbon blacks," Carbon, vol. 36, no. 9, pp. 1317-1325, 1998.

[23] H. P. Boehm, "Some aspects of the surface chemistry of carbon blacks and other carbons," Carbon, vol. 32, no. 5, pp. 759-769, 1994.

[24] V. Ettler, P. Piantone, and J.-C. Touray, "Mineralogical control on inorganic contaminant mobility in leachate from leadzinc metallurgical slag: experimental approach and long- term assessment," Mineralogical Magazine, vol. 67, no. 6, pp. 12691283, 2003.

[25] N. Zdankus, S. Vaikasas, and G. Sabas, "Impact of a hydropower plant on the downstream reach of a river," Journal of Environmental Engineering and Landscape Management, vol. 16, no. 3, pp. 128-134, 2008.

[26] K. M. Shams, G. Tichy, M. Sager, T. Peer, A. Bashar, and M. Jozic, "Soil contamination from tannery wastes with emphasis on the fate and distribution of tri- and hexavalent chromium," Water, Air, and Soil Pollution, vol. 199, no. 1-4, pp. 123-137, 2009.

[27] "Ordinance on the methods and conditions for the landfill of waste, categories and Operational requirements for waste landfills" (Croatian), Official Gazette No. 117/2007. 

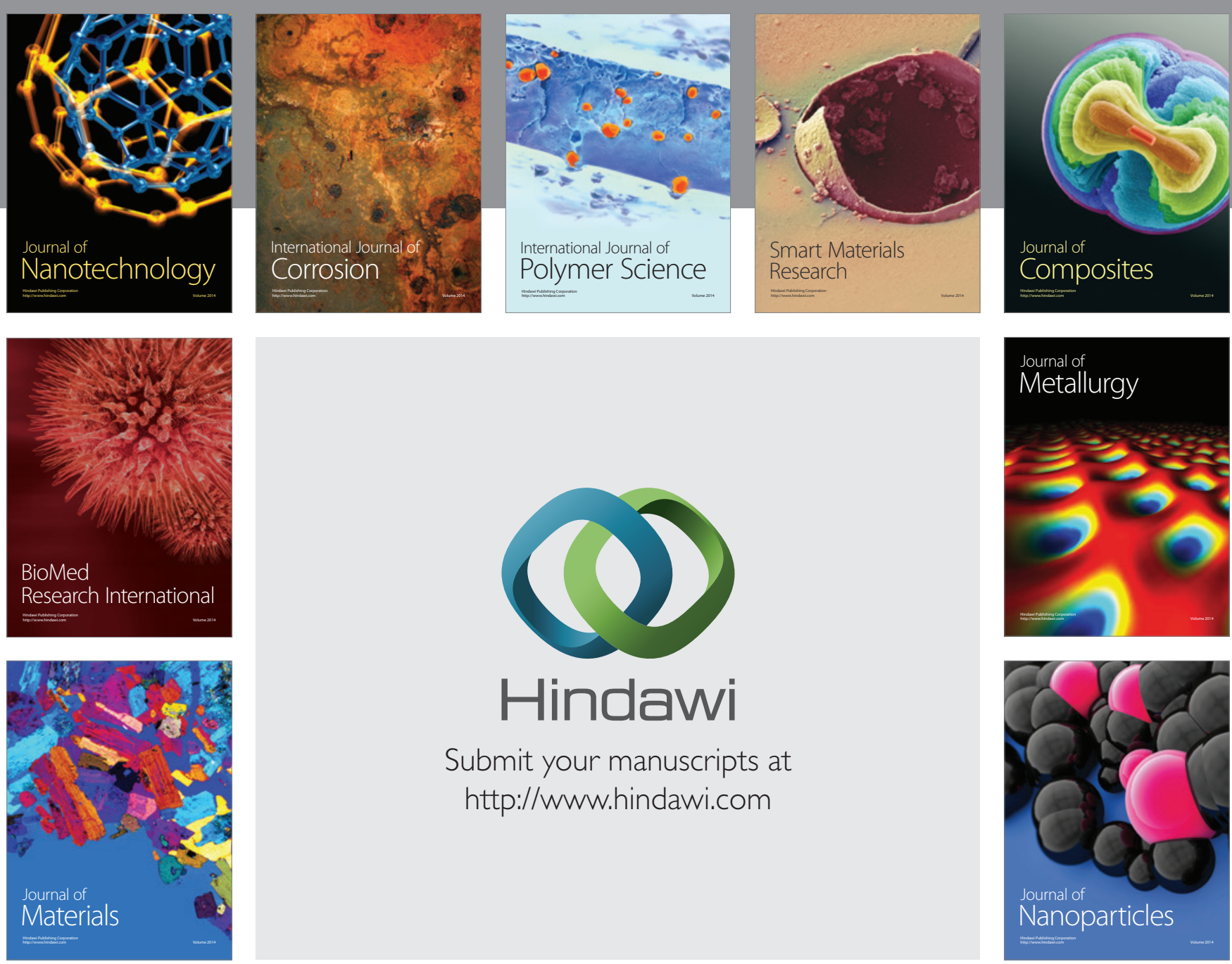

Submit your manuscripts at http://www.hindawi.com
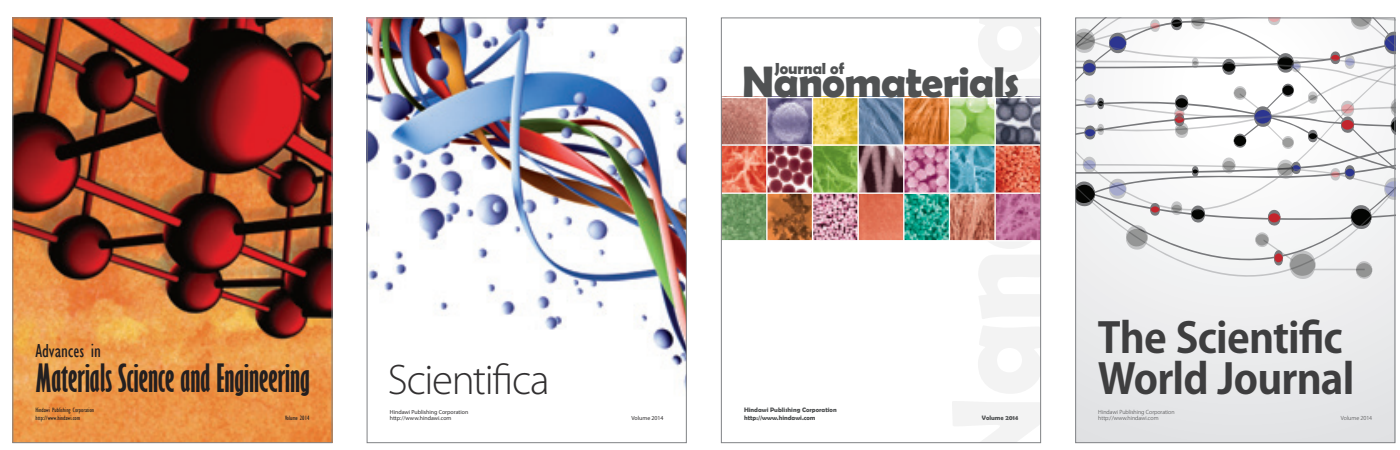

\section{The Scientific World Journal}
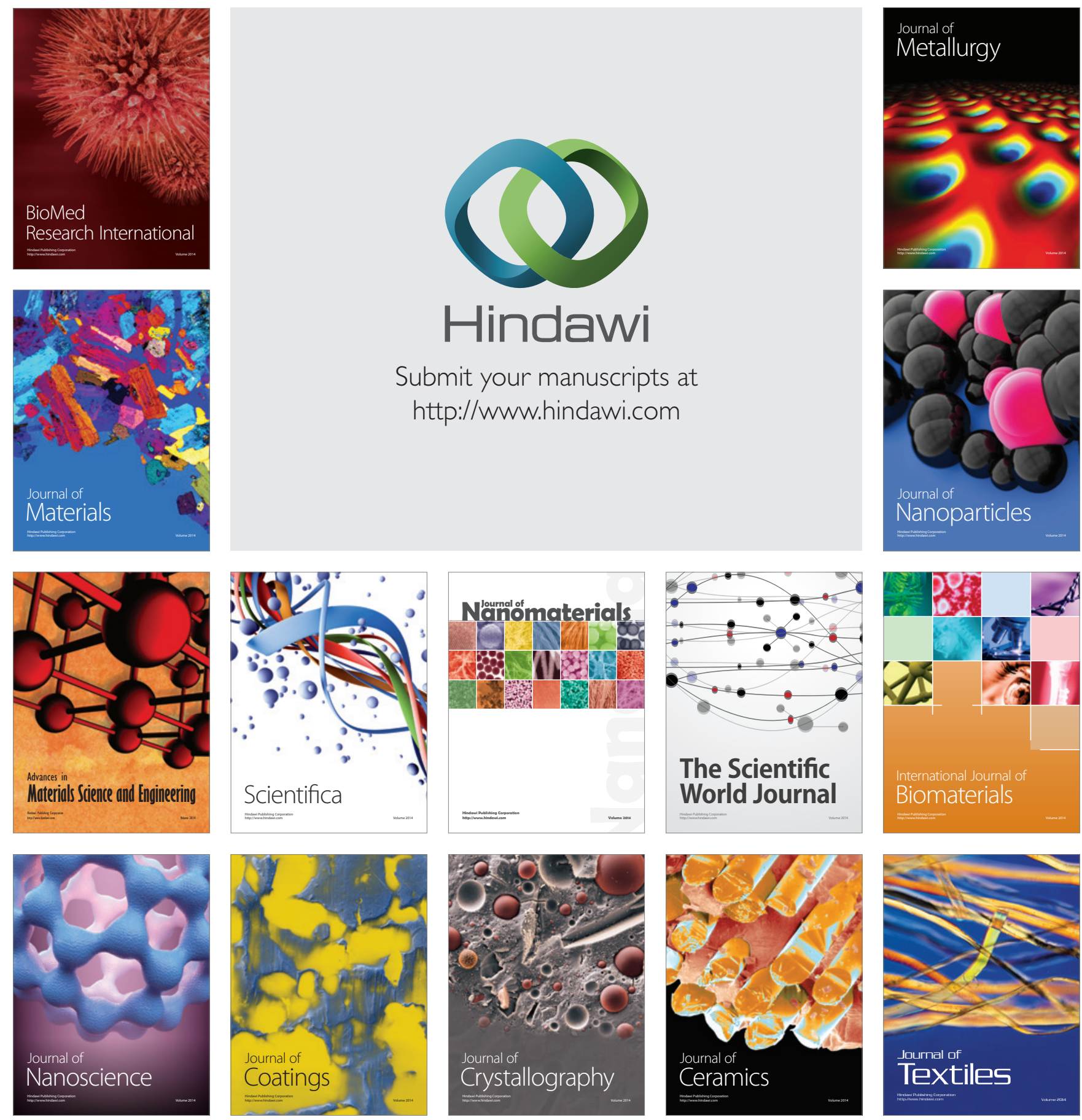